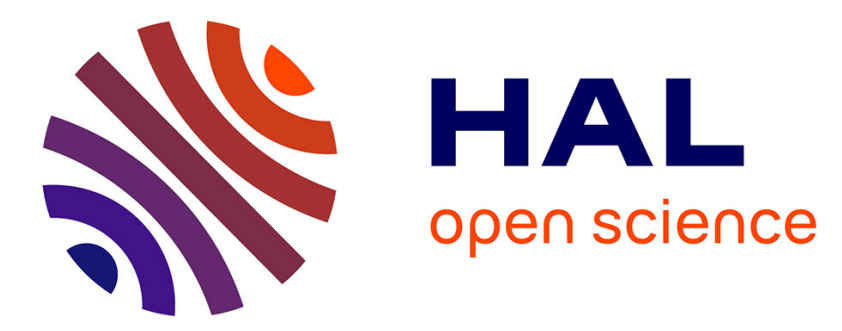

\title{
Long-term tests duration reduction for PEMFC $\mu$-CHP application
}

Elodie Pahon, Simon Morando, Raffaele Petrone, Marie-Cécile Péra, Daniel

Hissel, Nadia Steiner, Samir Jemei, Rafael Gouriveau, Didier Chamagne, Philippe Moçoteguy, et al.

\section{To cite this version:}

Elodie Pahon, Simon Morando, Raffaele Petrone, Marie-Cécile Péra, Daniel Hissel, et al.. Long-term tests duration reduction for PEMFC $\mu$-CHP application. International Journal of Hydrogen Energy, 2017, 42 (2), pp.1527-1533. 10.1016/j.ijhydene.2016.06.222 . hal-02131028

\section{HAL Id: hal-02131028 \\ https://hal.science/hal-02131028}

Submitted on 21 Oct 2021

HAL is a multi-disciplinary open access archive for the deposit and dissemination of scientific research documents, whether they are published or not. The documents may come from teaching and research institutions in France or abroad, or from public or private research centers.
L'archive ouverte pluridisciplinaire HAL, est destinée au dépôt et à la diffusion de documents scientifiques de niveau recherche, publiés ou non, émanant des établissements d'enseignement et de recherche français ou étrangers, des laboratoires publics ou privés. 


\title{
Long-term tests duration reduction for PEMFC $\mu$-CHP application
}

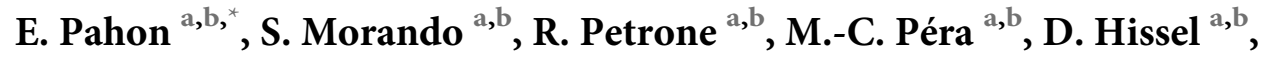 \\ N. Yousfi-Steiner ${ }^{a, b, c}$, S. Jemei ${ }^{a}$,b, R. Gouriveau ${ }^{\text {a,b }}$, D. Chamagne ${ }^{\text {a,b }}$, \\ P. Moçotéguy ${ }^{\mathrm{d}}$, N. Zerhouni ${ }^{\mathrm{a}, \mathrm{b}}$
}

Proton exchange membrane fuel cells (PEMFC) are extremely promising devices. Never-theless some technological constraints concerning system durability and reliability costs, still limit their large-scale production. In this framework, lifetime prediction and durability enhancement studies are mainly concerned. To solve this issue, methods based on Prog-nostic and Health Management (PHM) are developed. It is worth noting that these methods usually require to establish a consistent database concerning the system ageing referring to specific mission profiles. To this purpose, long-term tests are commonly performed. Among different applications, this paper will focus on two micro-cogeneration ( $\mu$-CHP) durability tests, based on the same load demand. The first test is realized in $1000 \mathrm{~h}$ while the second one is reduced to $500 \mathrm{~h}$ resulting in a compressed profile. We observed that the respective global voltage degradation rates are similar. Consequently a reflection is pro-posed to support accelerated tests protocol development.

\section{Introduction}

Proton exchange membrane fuel cell (PEMFC) appears nowadays to be a promising energy device to face energy transition challenges. Nevertheless, high cost and low durability are still the main bottlenecks for their deployment. So, research activities mainly focus on ageing characterization to enhance the system lifetime. In this framework, new approaches based on prognostic and health management (PHM) methods [1-3] are introduced to evaluate the remaining useful life (RUL). An example of RUL prediction is given in Refs. [4-6], where the performance of prediction of an echo state networks is analyzed on the voltage degradation. The main objective of the PHM is to reach the FC lifespan by improving the efficiency of the system control and by

* Corresponding author. FEMTO-ST, FCLAB, University Bourgogne Franche-Comté (UBFC), TechnHom, Rue Thierry Mieg, 90010 Belfort Cedex, France.

E-mail addresses: elodie.pahon@univ-fcomte.fr (E. Pahon), simon.morando@femto-st.fr (S. Morando), raffaele.petrone@femto-st.fr (R. Petrone). 
supporting maintenance and recovery actions. To develop PHM algorithms, several long duration tests are required resulting into extremely time consuming and very costly procedures. Then to reduce these constraints, the development of new accelerated stress test (AST) protocols to support lifetime prediction is an open question. The main contributions available in the literature are summed up in Ref. [7]. Authors reported the main stress factors influencing the PEMFC ageing that are commonly exploited to accelerate the degradation mechanisms. From this analysis, it results that high temperature condition is a common stress factor. Moreover, in the literature, different dynamic stress conditions like relative humidity $(\mathrm{RH})$ cycles, improper start and stop and sudden load variations are also used to accelerate the degradation-failure modes [7]. Nevertheless, to be consistent with the cell components ageing induced by real load conditions the main stressors have to be increased. According to [7], load cycling is the simplest mode to induce ageing acceleration. In this framework, previous studies focused on load cycles effects can be found in Bae et al. [8] and Jeon et al. $[9,10]$ works. These authors confirmed that increasing the load variation frequency can have a deep impact in FC ageing, especially for membrane degradation [9]. In this paper, the ageing effects induced by a real load profile are underlined. Their impact on system durability is analyzed by comparing the results obtained by compressing the reference cycle profile. For this purpose a first long duration test was performed during $1000 \mathrm{~h}$. Subsequently the same load profile was scaled to $500 \mathrm{~h}$. Experimental activity is presented in the next Section (context and experimental setup), while tests results are presented in Section experimental results. Results analysis and perspectives for future works on stack ageing acceleration are proposed in Section results analysis and suggestions.

\section{Context and experimental setup}

The proposed experimental activity has been done in the framework of the French ANR project PROPICE "Prognostics and Health Management of PEM Fuel Cell Systems" [11]. The project aims at establishing a robust prognostic approach for PEMFC in order to determine the RUL. During this project, both microcogeneration ( $\mu$-CHP) and transport profiles are tested. Tests durations are fixed to $1000 \mathrm{~h}$. This paper focus on the $\mu$-CHP profile tests.

\section{Test bench description}

A high power test bench (10 kWe), the characteristics of which are given in Table 1, has been used for experimental activity.

A picture representing the considered $10 \mathrm{kWe}$ test bench is proposed in Fig. 1. Both inlet and outlet gas properties are controlled, such as their flow rate, pressure, temperature and humidification. All the operating variables concerning fluids (1), electrical (2) and thermal flows (3) are recorded at a $1 \mathrm{~Hz}$ acquisition frequency all along the test by National Instruments ${ }^{\mathrm{TM}}$ device (3).

The gas flows, the cooling system and the electrical connections are schematized in Fig. 2, together with the different
Table 1 - Specifications of the $10 \mathrm{~kW}$ test bench.

Technical specifications

Range

\begin{tabular}{|c|c|}
\hline Cooling circuit & {$[20-80]^{\circ} \mathrm{C}$} \\
\hline Inlet gas temperature ${ }^{a}$ & {$[20-80]^{\circ} \mathrm{C}$} \\
\hline Inlet gas humidification $(\mathrm{RH})^{\mathrm{a}}$ & {$[0-100] \%$} \\
\hline Water flow rate & {$[0-20] \mathrm{Nl} / \mathrm{min}$} \\
\hline Air flow rate & {$[0-500] \mathrm{Nl} / \mathrm{min}$} \\
\hline Hydrogen flow rate & {$[0-100] \mathrm{Nl} / \mathrm{min}$} \\
\hline Gas pressure ${ }^{a}$ & {$[0-2.5]$ bar } \\
\hline Current & {$[0-1000] \mathrm{A}$} \\
\hline
\end{tabular}

${ }^{\text {a }}$ Both anode and cathode sides.

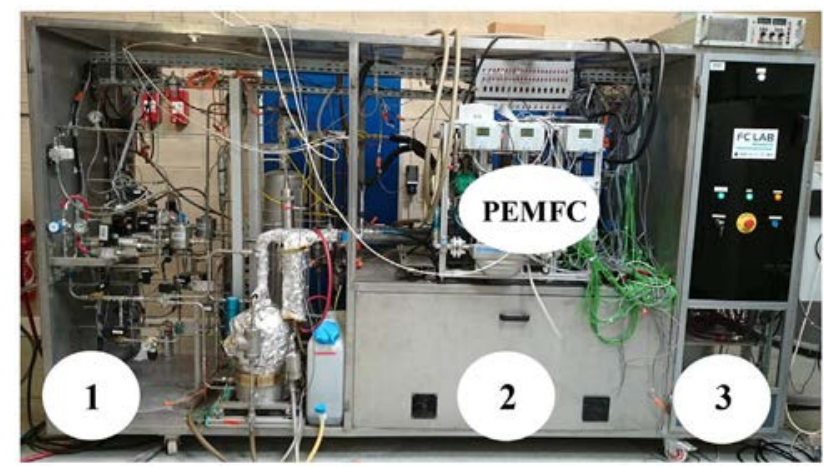

Fig. $1-10 \mathrm{~kW}$ test bench.

sensors locations. For a better understanding the sensors list is reported in Table 2 .

\section{PEMFC stack specifications}

Two 8-cells PEMFC stacks of $1 \mathrm{kWe}$ power are used for experimental activity; one for each test. The nominal specifications of the considered stacks are given in Table 3.

\section{Long duration $(1000 \mathrm{~h})$ test}

The experimental profile proposed in this section and illustrated in Fig. 3 is based on on-field measurements performed within the framework of a demonstration project where Electricity of France (EDF) was partner [12]. The reported $\mu$ CHP load profile simulates the behavior of a stationary PEMFC application during a complete year. Consequently the resulting load profile is obtained by combining in series 4 subperiods of $250 \mathrm{~h}$; one for each season. The specific PEMFC utilization (power demand) is linked to each of them as reported below.

- Winter: Steady state operating conditions at the maximal power demand for a period of $250 \mathrm{~h}$.

- Spring: composed by 2 steps:

- Load cycling [5 cycles; 1 cycle per day] by alternating maximal power and half power operating conditions.

- Steady state operation at the half power demand for a period of $120 \mathrm{~h}$.

- Summer: Duty cycle [11 cycles; 1 cycle per day] of which $12 \mathrm{~h}$ at half power and $12 \mathrm{~h}$ at Open Circuit Voltage (OCV). 


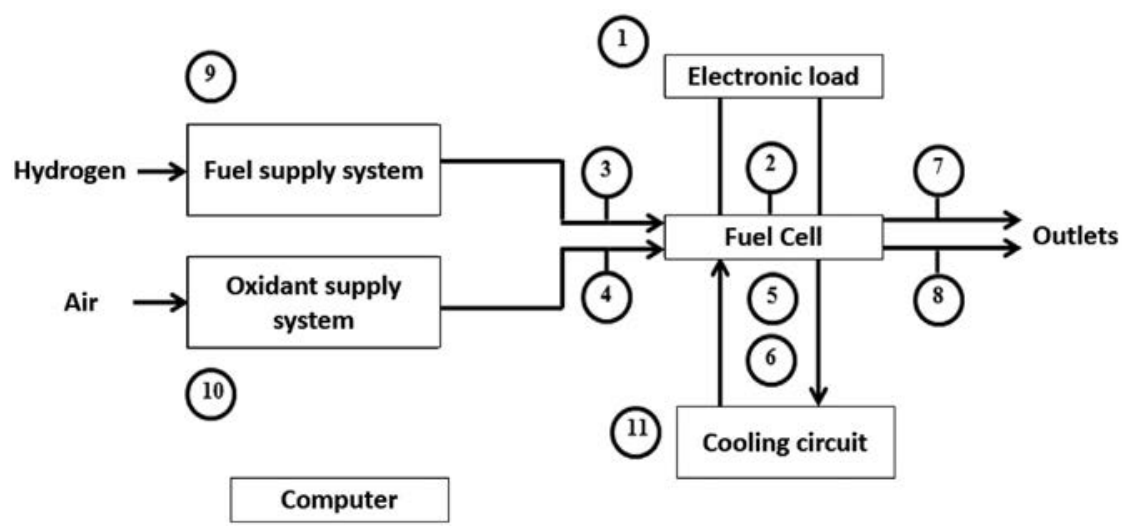

Fig. 2 - Locations of the different sensors on the test bench.

During OCV, the current value is closed to zero and gases are supplied at low flow rates.

- Autumn: similar to spring but reversed

- Steady state at half power conditions.

- Load cycling [5 cycles; 1 cycle per day].

Table 2 - Sensor list.

Measurements

Sensor

Current (I)

Stack voltage $(\mathrm{V})$

Cell voltages $\left(\mathrm{V}_{n}\right)$

Stack temperature $\left(\mathrm{TS}_{\text {eau }}\right)$

Hydrogen inlet temperature $\left(\mathrm{TH}_{2}\right.$ in)

Hydrogen outlet temperature ( $\mathrm{TH}_{2}$ out)

Air inlet temperature $\left(\mathrm{T}_{\text {Air }}\right.$ in)

Air outlet temperature $\left(\mathrm{T}_{\text {Air }}\right.$ out $)$

Hydrogen inlet relative humidity $\left(\mathrm{HRH}_{2}\right.$ in)

Hydrogen outlet relative humidity ( $\mathrm{HRH}_{2}$ out)

Air inlet relative humidity $\left(\mathrm{HR}_{\mathrm{Air}}\right.$ in)

Air outlet relative humidity ( $\mathrm{HR}_{\text {Air }}$ out)

Hydrogen inlet pressure $\left(\mathrm{PH}_{2}\right.$ in)

Hydrogen outlet pressure $\left(\mathrm{PH}_{2}\right.$ out)

Air inlet relative pressure $\left(\mathrm{P}_{\text {Air }}\right.$ in)

Air outlet relative pressure $\left(\mathrm{P}_{\text {Air }}\right.$ out $)$

Pressure drop $(\Delta \mathrm{P})$

Hydrogen inlet flow rate $\left(\mathrm{DH}_{2}\right.$ in)

Air inlet flow rate $\left(D_{\text {Air }}\right.$ in)

Water flow rate $\left(D_{\text {eau }}\right)$
During the test, both the polarization curves and the electrochemical impedance spectras (EIS) at low, mean and high current values are measured once a week. The same measurements are performed at the beginning and at the end of the test.

\section{Reduced $(500 \mathrm{~h})$ test}

The $500 \mathrm{~h}$ ageing test is obtained by scaling in time domain the $\mu$-CHP load profile applied for long duration test. In the load profile compression procedure, the load variation conditions and, in particular the ramps assumed to switch the different load values are kept the same as in the original profile, accordingly to stack dynamic limitations. On the contrary the sub-periods related to the steady state conditions are reduced as reported below. The new compressed profile is still composed by four sub-periods (seasons).

- Winter: $125 \mathrm{~h}$ at the maximal power.

- Spring: 5 cycles (2 per day) between the maximal power and the half power and $60 \mathrm{~h}$ in steady state conditions at the half power value.

- Summer: 11 duty cycles (2 per day) with $6 \mathrm{~h}$ at half power and $6 \mathrm{~h}$ at OCV.

- Autumn: $60 \mathrm{~h}$ at half power and 5 cycles between the half power and the maximal power.

During the test a new PEMFC stack of the same technology is used (c.f. Table 3). Measurements are scheduled at the

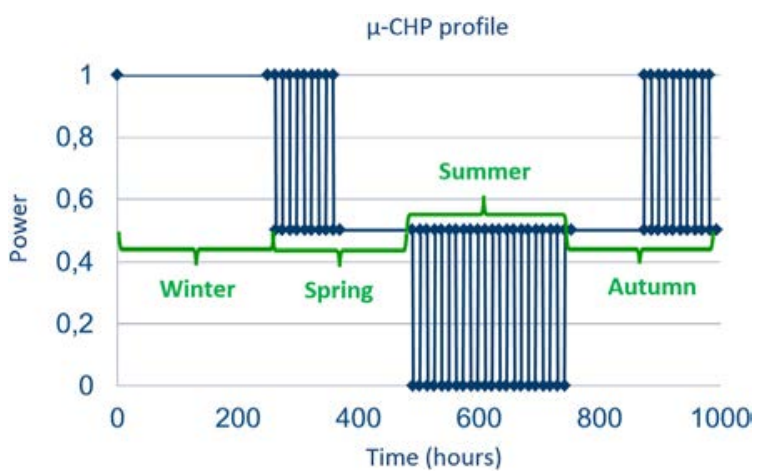

Fig. $3-\mu$-CHP normalized power profile.

Table 3 - 8-cell PEMFC nominal specifications.

\begin{tabular}{ll} 
Specifications & \multicolumn{1}{c}{ Value } \\
\hline Active area & $220 \mathrm{~cm}^{2}$ \\
Dimensions & $220 \times 160 \times 186 \mathrm{~mm}$ \\
Cooling (water) flow rate & $2 \mathrm{l} / \mathrm{min}$ \\
Anode/cathode stoichiometry & $1.5 / 2$ \\
Anode/cathode inlet pressure & $150 / 150 \mathrm{kPa}$ \\
Pressure drop & $30 \mathrm{kPa}$ \\
Temperature & $80{ }^{\circ} \mathrm{C}$ \\
Relative humidity anode/cathode & $50 / 50 \%$ \\
Current density & $0.5 \mathrm{~A} / \mathrm{cm}^{2}$ \\
\hline
\end{tabular}

\footnotetext{
${ }^{a}$ Both anode and cathode sides.
} 
beginning of the test (T0) and also at the end of each subperiods.

\section{Experimental results}

To perform the experiments, the power demand profile shown in Fig. 3 is translated into a current density profile.

\section{Long-duration test results}

The resulting load profile obtained for the $1,000 \mathrm{~h}$ ageing test is shown in Fig. 4, while the corresponding stack voltage response is given in Fig. 5 .

It is possible to observe that the maximal power demand is associated to a maximal current density value of $0.77 \mathrm{~A} / \mathrm{cm}^{2}$, while the half power state corresponds to $0.38 \mathrm{~A} / \mathrm{cm}^{2}$. As a first result, the maximal power operating condition, corresponding to the winter sub-period, severely affects the system performance. The resulting critical voltage drop is visible on Fig. 5. The stack voltage response decreases under the warning level (red (in the web version) line in Fig. 5). Consequently to perform the whole test, the current density values corresponding to the maximal and half load modes were changed. The new ones are fixed to $0.45 \mathrm{~A} / \mathrm{cm}^{2}$ and $0.23 \mathrm{~A} / \mathrm{cm}^{2}$, respectively. As a consequence of the maximal power mode, the upper limits of the polarization curve measurements changed, as shown in Fig. 6 . Afterwards, the 3 reference values considered to perform the EIS measurements are also changed, resulting: $0.09,0.23$ and $0.38 \mathrm{~A} / \mathrm{cm}^{2}$. The impact of ageing on the polarization curves is presented in Fig. 6, according to the reference load profile (1000 h).

Fig. 7 represents the EIS evolutions with ageing for a current density value of $0.38 \mathrm{~A} / \mathrm{cm}^{2}$. A frequency range comprised between $5 \mathrm{kHz}$ and $100 \mathrm{mHz}$ is considered for measurements. The spectra evolutions underline a sensible growth of both activation and diffusion losses, in accordance with the polarization curves evolutions presented in Fig. 6.

For a better evaluation of the voltage degradation, the voltage drop is given depending on the time, in Table 4. Results are evaluated at the same current density value of $0.38 \mathrm{~A} /$ $\mathrm{cm}^{2}$. After $1016 \mathrm{~h}$ of operation a global voltage degradation rate of $597 \mu \mathrm{V} / \mathrm{h}$ is observed for the whole stack, corresponding to $75 \mu \mathrm{V} / \mathrm{h} /$ cell. The partial information at 147, 308, 536 and $688 \mathrm{~h}$ are also reported to compare the voltage degradation rate during the different sub-periods. The total degradation

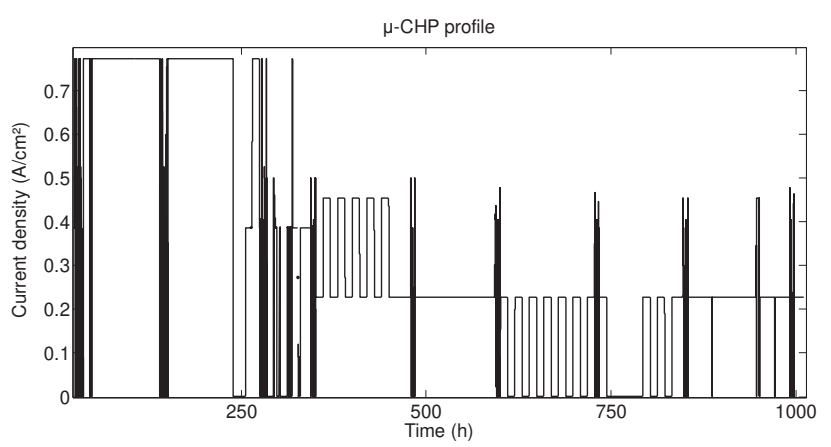

Fig. 4 - 1000 h $\mu$-CHP load profile.

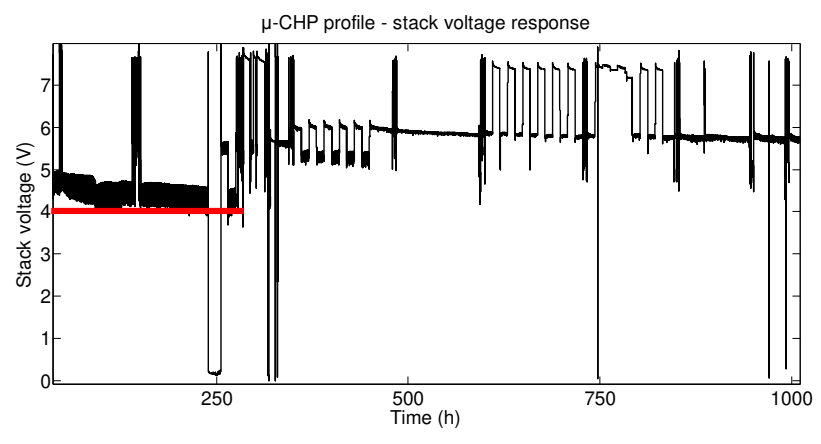

Fig. 5 - Stack voltage response (1000 h test).

value of $75 \mu \mathrm{V} / \mathrm{h} /$ cell averages all the degradations rates obtained in time. A sensible growth in voltage degradation can be observed at the beginning, during the winter season $[\mathrm{TO} ; \mathrm{TO}+147 \mathrm{~h}]$. Therefore according to the stack voltage evolution (see Fig. 5), the steady state operation at high current density shows a deep impact in performance losses. Nevertheless, the induced effects resulted partially reversibles. This behavior can be verified considering measurements achieved after the load variation (at $t=308 \mathrm{~h}$ ). The voltage degradation was recovered at about the $50 \%$ (from 170 to $81 \mu \mathrm{V} /$ cell/h at $0.38 \mathrm{~A} / \mathrm{cm}^{2}$ ). Considering the measurements both at the beginning and at the end of the summer $(t=536 \mathrm{~h}$ and $t=688 \mathrm{~h})$, the voltage degradation rate is quite constant (116 and $109 \mu \mathrm{V} / \mathrm{cell} / \mathrm{h}$ at $0.38 \mathrm{~A} / \mathrm{cm}^{2}$, respectively). Finally autumn conditions show an additional recovery. Concluding, the steady state conditions at high current density and duty cycle at OCV seems to show higher voltage losses, while load variation at mean load conditions seems to show a recovery effect. This behavior can be mainly due to the fact that the load profile dynamics imposed during the test are opportunely lower than the fuel cell allowable dynamics. In this case, not significant degradations (irreversibilities) are induced at mean load, but on the contrary the load variation seems to result in a regenerative effect, broking the system losses inertia due to steady operation. Additional consideration are reported in the next section, where the voltage degradation rate evaluated both at $1000 \mathrm{~h}$ and $500 \mathrm{~h}$ are compared.

\section{Reduced test results}

The current density profile of the $500 \mathrm{~h}$ experiment is reported in Fig. 8, while the corresponding stack voltage is given in Fig. 9. A maximal current density of $0.45 \mathrm{~A} / \mathrm{cm}^{2}$ is considered and a value of $0.23 \mathrm{~A} / \mathrm{cm}^{2}$ is considered for the half load conditions. So it is worth underlining that the current densities values considered in both $1000 \mathrm{~h}$ and $500 \mathrm{~h}$ profiles are the same, except for the winter steady state conditions. Finally, the same metrics proposed in the previous paragraph are considered.

Fig. 10 illustrates the evolution of polarization curves during the $500 \mathrm{~h}$, while EIS evolutions at $0.38 \mathrm{~A} / \mathrm{cm}^{2}$ are shown in Fig. 11. Comparing Figs. 6 and 10, we observe that the polarization curve obtained at $500 \mathrm{~h}$ in the case of the long duration test (red (in the web version) curve in Fig. 6) is quite similar to the polarization curve measured at the end of the $500 \mathrm{~h}$ test 


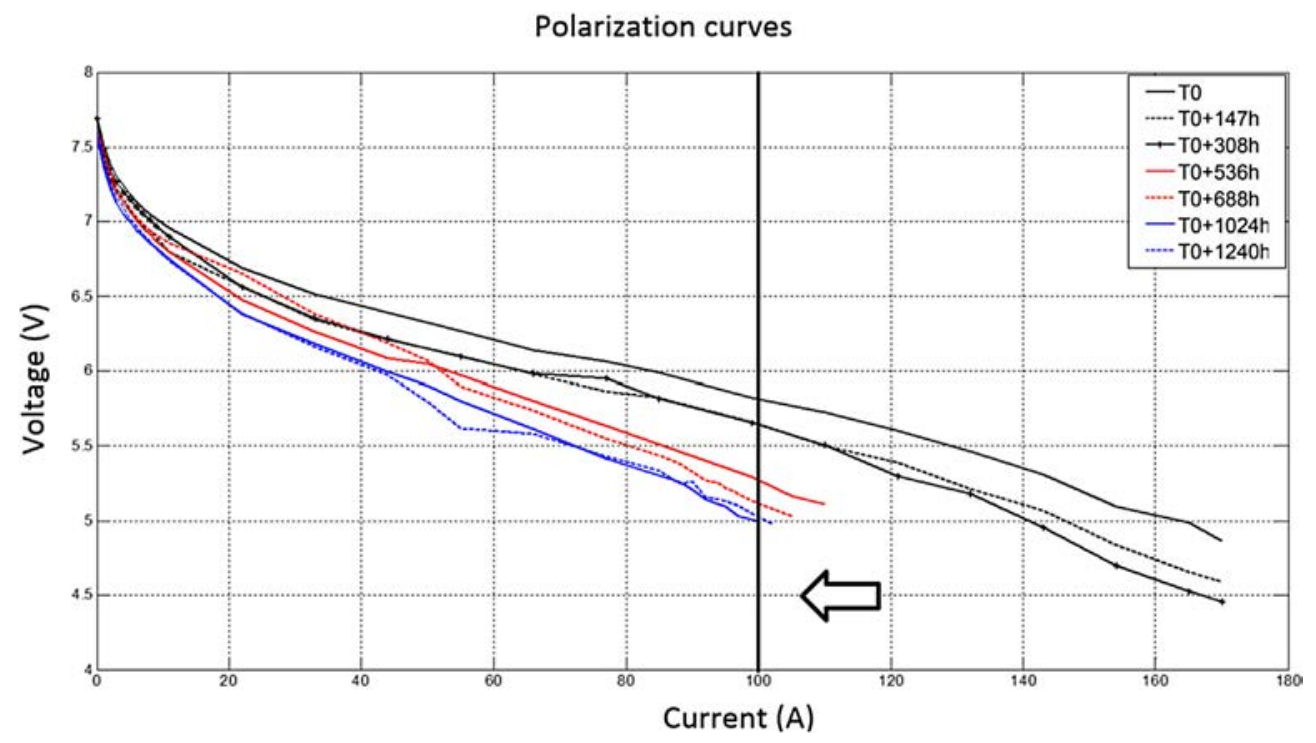

Fig. 6 - Ageing impact on the polarization curves (1000 h test).

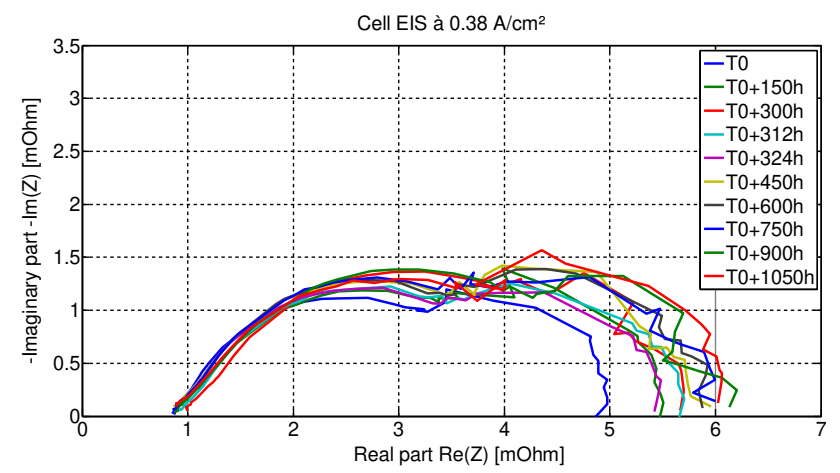

Fig. 7 - Ageing impact on the EIS measurements (1000 h).

Table 4 - Degradations of the 8-cell stack @ $0.38 \mathrm{~A} / \mathrm{cm}^{2}$.

Time Degradation $(\mu \mathrm{V} /$ cell $/ \mathrm{h})$

$[\mathrm{TO} ; \mathrm{T} 0+147 \mathrm{~h}]$

$[\mathrm{TO} ; \mathrm{TO}+308 \mathrm{~h}]$

$[\mathrm{TO} ; \mathrm{TO}+536 \mathrm{~h}]$

$[\mathrm{TO} ; \mathrm{TO}+688 \mathrm{~h}]$

$\left[\mathrm{TO} ; \mathrm{T}_{\text {end }}\right]$

170

81

116

109

75

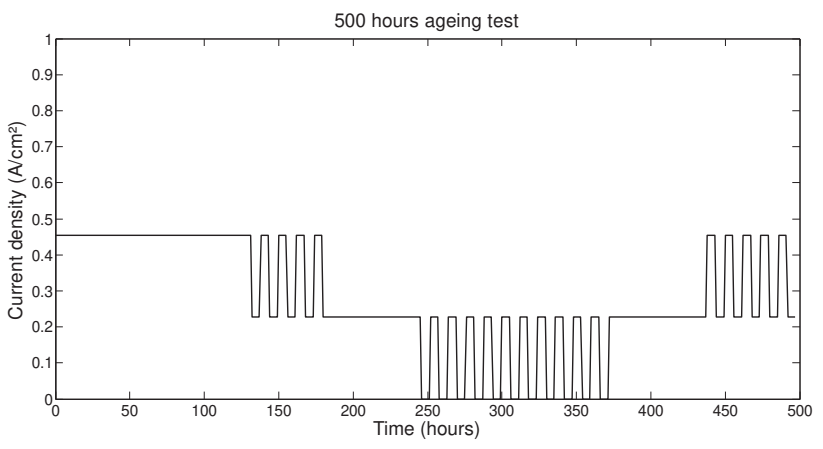

Fig. 8 - 500 h $\mu$-CHP load profile.

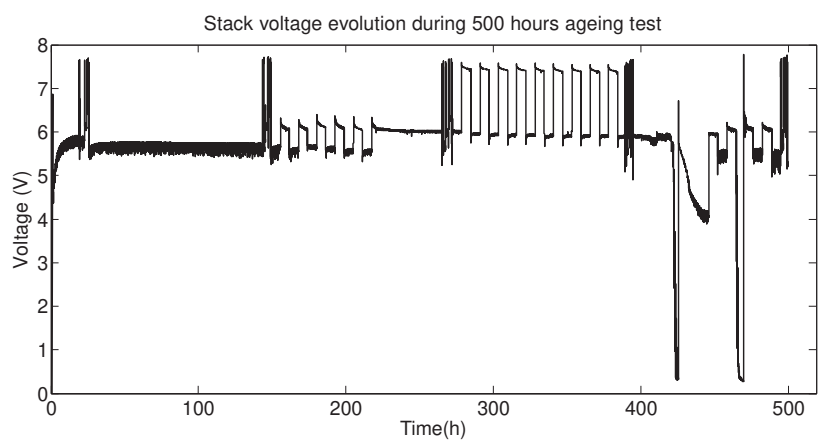

Fig. 9 - Stack voltage response (500 h test).

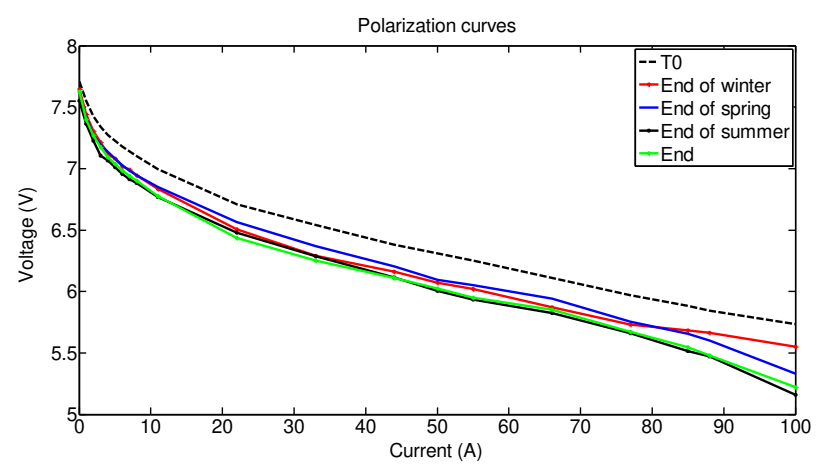

Fig. 10 - Ageing impact on the polarization curves obtained during the reduced test $(500 \mathrm{~h})$.

(green (in the web version) curve in Fig. 10). While considering the impedance spectra acquired at $0.38 \mathrm{~A} / \mathrm{cm}^{2}$ both in longduration and reduced test (Figs. 7 and 11), we observe that the same performance losses (activation and diffusion) are influenced. Losses intensity are lower in case of the reduced duration test, but this behavior can be due to a difference on the two first spectras measured on each stack, at the beginning of the two tests (T0). 


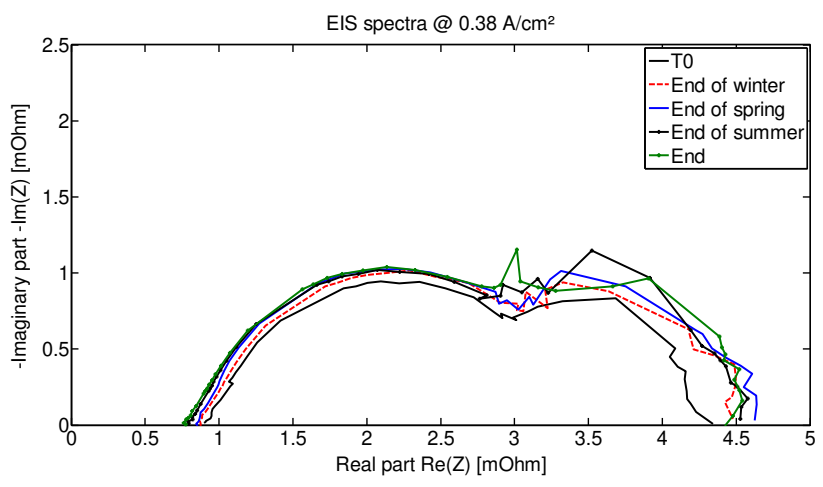

Fig. 11 - Ageing impact on the EIS measurements.

As for long duration test, the voltage drop versus time is reported in Table 5 . After $500 \mathrm{~h}$ of operations, a voltage degradation rate of $611 \mu \mathrm{V} / \mathrm{h}$ is observed for the whole stack, corresponding to $76 \mu \mathrm{V} / \mathrm{h} /$ cell. The information at the end of each season are also reported to compare the voltage rate variation during the different sub-periods. The global voltage degradation rate in both the tests is similar. This point is consistent with the polarization curve similitude at $500 \mathrm{~h}$. For more details, a deeper analysis is presented in the next section. It is worth noting that also in this case, winter and summer sub-periods appear as the worst conditions, inducing both reversible and irreversible losses. The load variations at mean load values recover the reversible losses allowing the irreversible voltage degradation evaluation.

\section{Results analysis and suggestions}

Results reported in paragraphs 3.1 and 3.2 exhibit the impact of load cycle profile in system ageing. Tests performed both at 1000 and $500 \mathrm{~h}$ mainly show that even if the test duration is reduced, the global voltage degradation rate is the same. The results reported in Tables 4 and 5 , obtained at $0.38 \mathrm{~A} / \mathrm{cm}^{2}$, underline that steady state conditions at high current density have an initial deep impact on voltage degradation. In this way, the voltage rates obtained in the case of high load condition in both tests are quite similar. Indeed, if long duration test response showed a critical voltage drop (see Fig. 5), this effect seems to be partially recovered during the spring subperiod. This phenomenon was mainly reversible and the voltage is recovered by performing a polarization curve. Moreover by analyzing the voltage rate behavior during the different seasons sub-periods it is possible to state that summer load variations (between OCV and half load values) also have an important impact, while during spring and autumn

Table 5 - Degradations of the 8-cell stack @ $0.38 \mathrm{~A} / \mathrm{cm}^{2}$.

\begin{tabular}{lc} 
Time & Degradation $(\mu \mathrm{V} / \mathrm{cell} / \mathrm{h})$ \\
\hline$[\mathrm{TO} ; \mathrm{TO}+125 h]$ & 180 \\
{$[\mathrm{TO} ; \mathrm{TO}+245 h]$} & 103 \\
{$[\mathrm{TO} ; \mathrm{TO}+377 \mathrm{~h}]$} & 116 \\
{$\left[\mathrm{TO} ; \mathrm{T}_{\text {end }}\right]$} & 76 \\
\hline
\end{tabular}

sub-periods a partial recovery is observed. To have a better understanding, the unit-less voltage drops evaluated at $0.38 \mathrm{~A} /$ $\mathrm{cm}^{2}$ are presented in Fig. 12. The voltage drop values are normalized with respect to the reference voltage value measured at $j=0.38 \mathrm{~A} / \mathrm{cm}^{2}$ and $\mathrm{t}=\mathrm{T} 0$. The red (in the web version) line in Fig. 12 represents the global voltage degradation rate. We can observe that at the end of both tests, the related voltage drops are closed to this line. The voltage degradation rate increasing and partial recovery are represented by the black $(1,000 \mathrm{~h})$ and blue $(500 \mathrm{~h})$ full-lines slope variations.

For a long duration test of $1000 \mathrm{~h}$, the stack operates at quite long stationary conditions. These operations induce both irreversible and recoverable voltage losses. In case of $500 \mathrm{~h}$ test, the steady state conditions durations are reduced, while the load variation are kept the same. This procedure seems to conserve the global voltage degradation rate, suggesting that the same reversible and irreversible processes are induced in both the ageing tests. Therefore the reduction of the steady state operation seems not affecting the global voltage degradation rate. Nevertheless, accelerating the cell ageing means increasing the voltage degradation rate. Consequently, the results presented in this work do not represent an accelerated test but characterize an important support in AST procedure development. For a better understanding, future studies will be oriented to check the real impact of stationary conditions duration in voltage degradation with respect to the load dynamics. This information will be fundamental in AST procedure development, indicating the limit conditions to respect in steady state duration reduction during the test. Subsequently the ageing acceleration will be induced stressing the load variation conditions. For this purpose, a first suggestion is to increase the number of load variation repetitions proportionally to the reference cycle dynamics. This procedure can be also implemented by increasing the reference load cycle frequency, which means accelerating the real load dynamics. These considerations are in accordance with AST works presented in Refs. [7-10]. These proposals will allow the development of a suitable AST procedure able to link accelerated and real ageing consistently with real load profile dynamics. Therefore it will be finally possible to reduce the actual test duration and costs for durability analysis and lifetime prediction application.

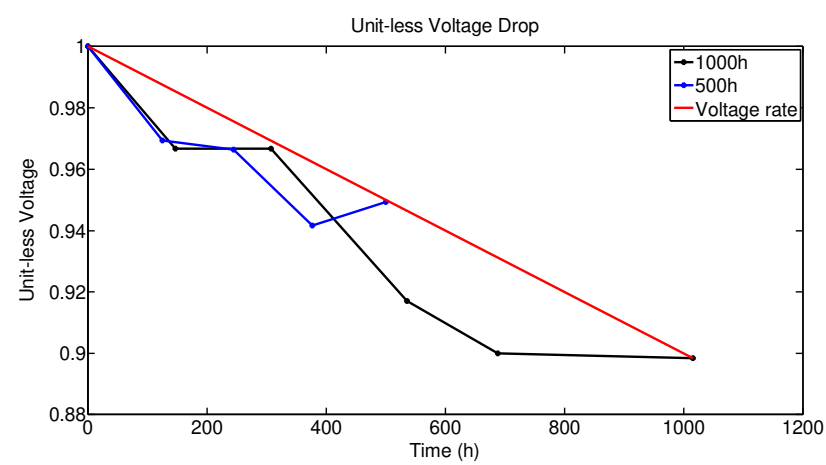

Fig. 12 - Unit-less voltage drop and degradations rate comparison for $1,000 \mathrm{~h}$ and $500 \mathrm{~h}$ tests. 


\section{Conclusion}

This paper presents French ANR project PROPICE experimental results. Two ageing tests are proposed. The first one is a long duration test of $1000 \mathrm{~h}$, developed for simulating a $\mu$ CHP load demand profile for a complete year. Effects of long duration stationary conditions, OCV operations and sudden load variations are analyzed. The second test of $500 \mathrm{~h}$ reproduces the same load profile scaled in time domain. The effects of the long-term test duration reduction on voltage decay are then analyzed. A similar voltage degradation rate is observed at the test end in both cases. Moreover, the partial voltage drops analysis suggests that it is possible to induce similar voltage decays by reducing the steady-state operations duration and considering the same load variations. These results are then assumed to be a key point to propose new methods to reduce long duration tests by increasing the real load cycle frequency.

\section{Acknowledgment}

The authors would like to thank the ANR project PROPICE (ANR-12-PRGE-0001) and the Labex ACTION project (contract "ANR-11-LABX-01-01") both funded by the French National Research Agency for their support.

\section{R E F E R E N C E S}

[1] Jouin M, Gouriveau R, Hissel D, Péra M-C, Zerhouni N. Prognostics and health management of PEMFC - state of the art and remaining challenges. Int J Hydrogen Energy 2013;38(35):15307-17.

[2] Lechartier E, Laffly E, Péra M-C, Gouriveau R, Hissel D, Zerhouni N. Proton exchange membrane fuel cell behavioral model suitable for prognostics. Int J Hydrogen Energy 2015;40(26):83848397.

[3] Silva RE, Gouriveau R, Jeme S, Hissel D, Boulon L, Agbossou K, et al. Proton exchange membrane fuel cell degradation prediction based on Adaptive Neuro-Fuzzy Inference Systems. Int J Hydrogen Energy 2014;39(21):1112811144.

[4] Morando S, Jemei S, Gouriveau R, Zerhouni N, Hissel D. Fuel cells remaining useful lifetime forecasting using echo state network. IEEE Vehicle Power and Propulsion Conference (VPPC) 2014, p. 1-6.

[5] Jouin M, Gouriveau R, Hissel D, Péra M-C, Zerhouni N. Prognostics of PEM fuel cell in a particle filtering framework. Int J Hydrogen Energy 2014;39(1):481494.

[6] Bressel M, Hilairet M, Hissel D, Ould-Bouamama B. Remaining useful life prediction and uncertainty quantification of proton exchange membrane fuel cell under variable load. IEEE Trans Ind Electron 2016;PP(99).

[7] Petrone R, Hissel D, Péra M-C, Chamagne D, Gouriveau R. Accelerated stress test procedures for PEM fuel cells under actual load constraints: state-of-art and proposals. Int J Hydrogen Energy 2015;40:12489-505.

[8] Bae SJ, Kim S-J, Park J-I, Park C-W, Lee J-H, Song I, et al. Lifetime prediction of a polymer electrolyte membrane fuel cell via an accelerated startup-shutdown cycle test. Int J Hydrogen Energy 2012;37:9775-81.

[9] Jeon Y, Juon SM, Hwang H, Park J, Shul Y-G. Accelerated lifetime tests including different load cycling protocols for high temperature polymer electrolyte membrane fuel cells. Electrochem Acta 2014;148:15-25.

[10] Jeon Y, Na H, Hwang H, Park J, Hwang H, Shul Y. Accelerated life-time test protocols for polymer electrolyte membrane fuel cells operated at high temperature. Int J Hydrogen Energy 2015;40:3057-67.

[11] 2013-2016: ANR PROGELEC PROPICE: Prognostics et Health Management de systèmes Piles à Combustible de type PEMFC, available on http://www.propice.ens $2 \mathrm{~m}$.fr/.

[12] Moçotéguy P, Al-Naswari B, Aslanides A. Field testing of vaillant EURO 2 PEM fuel cell heating appliance for $\mu$-CHP in residential application. In: International workshop on degradation issues in fuel cells, Hersonissos, Crete; 2007. 